
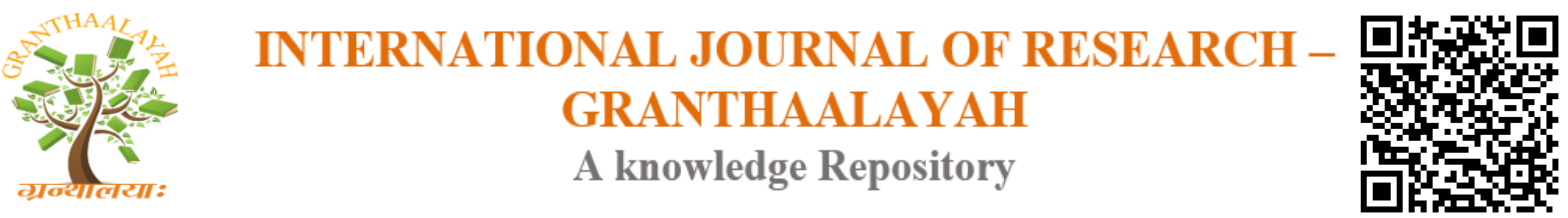

Science

\title{
AEGLE MARMELOS A POTENTIAL MEDICINAL TREE: AN OVERVIEW
}

\author{
Shail Bala Sanghi ${ }^{1}$, Sabira Mushtaq ${ }^{2}$ \\ ${ }^{1,2}$ Government M.L.B. Girls P.G. (Autonomous) College, Bhopal, (M.P.), India
}

\begin{abstract}
Aegle marmelos family rutaceae is an alleged ayurvedic medicinal tree commonly known as the bael. It is medium sized tree growing throughout the forest of India of altitude 1200 meter. It is found all over India, from sub-Himalayan forest, Bengal, central and south India. It is considered to be a holy tree in India. Various parts of this plant such as leaves, roots, seed, bark and fruit, possess anti-microfilarial, antifungal, immunomodulatory, anti-proliferative, wound healing, antifungal, analgesic, anti-inflammatory, antipyretic, hypoglycaemic, antidyslipidemic, antifertility, and insecticidal activity. Various phytopharmacological evaluations have been reported in this writing for the important potential of the Aegle marmelos.
\end{abstract}

Keywords: Aegle Marmelos; Leaves; Fruit; Bark; Pharmacological Properties.

Cite This Article: Shail Bala Sanghi, and Sabira Mushtaq. (2017). "AEGLE MARMELOS A POTENTIAL MEDICINAL TREE: AN OVERVIEW." International Journal of Research - Granthaalayah, 5(8), 63-66. https://doi.org/10.29121/granthaalayah.v5.i8.2017.2183.

\section{Introduction}

\subsection{Plant Description}

Bael (Aegle Marmelos (Linn), family Rutacae, is also known as Bale fruit tree, is a moderate sized, slender, aromatic tree, $6.0-7.5 \mathrm{~m}$ in height, and 90 to $120 \mathrm{~cm}$ in girth, with a somewhat fluted bole of 3.0-4.5 meter growing wild throughout the deciduous forests of India, ascending to an altitude of 1200 meter in the western Himalayas and also occurring in Andaman island.[1] This is generally considered as sacred tree by the Hindus, as its leaves are offered to Lord Shiva during worship. According to Hindu mythology, the tree is another form of Lord Kailashnath.[2] Leaves, fruit, stem and roots of this tree at all stages of maturity are used as ethno medicine against various human ailments.

\subsection{Chemical Constituents}

Various phytoconstituents have been isolated from the various parts of Aegle marmelos, which may be categorized as; [3] 
Table1: Phytoconstituents isolated from various parts of Aegle marmelos

\begin{tabular}{|l|l|l|}
\hline Sr.no. & Part & Phytoconstituents \\
\hline 01 & Leaf & $\begin{array}{l}\text { Skimmianine, Aegeline, Lupeol, Cineol, Citral, Citronella, Cuminaldehyde, } \\
\text { Eugenol. }\end{array}$ \\
\hline 02 & Bark & $\begin{array}{l}\text { Skimmianine, Fagarine, Marmin 3. Fruit Marmelosin, Luvangetin, Aurapten, } \\
\text { Psoralen, Marmelide, Tannin. }\end{array}$ \\
\hline
\end{tabular}

\section{Traditional Uses of Bael Tree Parts for Medicinal Purpose}

The different parts of Bael are used for various therapeutic purposes, such as for treatment of Asthma, Anaemia, Fractures, Healing of Wounds, Swollen Joints, High Blood Pressure, Jaundice, Diarrhoea Healthy Mind and Brain Typhoid Troubles during Pregnancy. [4] Aegle marmelos has been used as a herbal medicine for the management of diabetes mellitus in Ayurvedic, Unani and Siddha systems of medicine in India [5], Bangladesh [6] and SriLanka.[7] Flowers are useful in diarrhea, excessive thirst, vomiting and eye disorders and it is advisable as diet in eruptive boils.[8]

\section{Various proved therapeutic values of Aegle marmelos:}

1) Wound Healing Activity: Effect of topical and intraperitoneal administration of methanolic extract of Aegle marmelos ointment and injection was studied respectively on two types of wound models in rats, the excision and the incision wound model. Both the injection and the ointment of the methanolic extract of Aegle marmelos produced a significant response in both of the wound type tested. In the excision model the extract treated wounds were found to epithelialize faster and the rate of wound contration was higher, as compared to control wounds. The extract facilitated the healing process as evidenced by increase in the tensile strength in the incision model. The results were also comparable to those of a standard drug nitrofurazone.[9]

2) Analgesic: The methanol extract of leaves of Aegle marmelos at a dose level of 200 and $300 \mathrm{mg} / \mathrm{kg}$ showed significant analgesic activity on acetic acid-induced writhing and tail flick test in mice. 10

3) Anti-Diabetic Activity: Aqueous extract of Aegle marmelos leaves, was evaluated for hypoglycemic and antioxidant effect by Upadhya $S$ et al ( 2004), by using alloxon induced diabetes in male albino rats and proposed AML may be useful in the long-term management of diabetes.[11] Similarly, The anti hyperlipidaemic activity of aqueous extract of Aegle marmelos fruits was demonstrated by P.S. Marinzene et al (2005), using the streptozotocine induced diabetic wistar rats.[12] Sunderam et al, (2009) worked on alcoholic extract of Aegle Marmelos, Momordica Charantia and Eugenia Jambolana separately; against Streptozotocine induced diabetic rats and confirmed their protective activity against laboratory induced cell necrosis, [13] Where as, Kuttan \& Sabu ( 2004) studied on leaf extract of Aegle Marmelos on Alloxane induced diabetes and reported that used extract was enough capable to reduce oxidative stress by scavenging lipid peroxidation and enhancing certain Anti-oxidant levels which causes lowering of elevated blood glucose level.[14] Beside of all above cited work, Hema \& Lalithakumari (1999) had presented a tremendous results of Aegle Marmelos and documented its hypoglycemic action along with other pharmacological actions on molecular level.[15] 
4) Hepatoprotective Activity: Singanan et al, (2007) worked on Aegle Marmelos leaf extract on alcohol induced liver injury in albino rats and presented data of excellent hepatoprotective effects. [16] Similarly, Ramnik S (2008), also demontrated that aqueous extarct of bael fruit pulp and seeds are effective in the treatment and prevention of CCI4 induced hepatic toxicity. [17]

5) Antimicrobial Activity: Maheshwari et al, (2009) studied on ethnolic ectract of dried fruit pulp of Aegle Marmelos against various intestinal pathogens i.e. Shigella boydii, S. sonnei \& S. Flexneri and proposed that certain phytochemicals including Phenols, Tannins and Flavonoids were effective against all.[18] It was also confirmed by Kaur et al, ( 2009) by getting treat E. Coli with Aegle Marmelos fruit extract. [19] In consonance, Citarasu et al, (2003) also experimented Aegle Marmelos on certain pathogenic bacteria like Salmonella typhi, Pseudomonas aeruginosa, Aeromonas hydrophyla \& Vibrio sp., and concluded its positive bactericidal effects. [20]

\section{Conclusion}

Numerous pharmacological studies have been conducted on different parts of Aegle marmelos. The present literature supports the potential of Aegle marmelos as a medicinal tree. It is quite evident from this review that Aegle marmelos contains a number of phytoconstituents which reveals its uses for various therapeutic purposes. The Plant or its individual parts can be used for the treatment of various disorders in human being such as, diabetes, liver toxicity, fungal infection, microbial infection, inflammation, pyrexia and to relieve pain. Still, more research can be done to investigate the unexplored and unexploited potential of this plant and to investigate the mechanism of actions with other therapeutic activities.

\section{References}

[1] C.S.I.R.(1985), “ The wealth of India" National Institute of Science communication and Information Resources", Volume- I (A), 86

[2] Purohit S. S and Vyas S. P, "In: Aegle marmelos Correa ex Roxb,(Bael), Medicinal plant cultivation- A scientific approach", Agrobios, Jodhpur, 2004. P.P.498-504

[3] Maity P., Hansda D., Bandyopadhyay U. \& Mishra D.K., ( 2009) "Biological activities of crude extracts of chemical constituents of Bael, Aegle marmelos (L.) Corr." Indian Journal of Experimental Biology, Vol 47, p.p. 849-861

[4] Saswati Parichha 2004. "Bael (Aegle Marmelos): Nature's Most Natural Medicinal Fruit”, Orissa Review.

[5] Kar A. Choudhry B. K. and Bandhopadhyay N. G. (2003), "Comparative evaluation of hypoglycemic activity of some Indian medicinal plants in alloxan diabetic rats" J Ethnopharmacol. 84, Page No.105-108.

[6] Lampronti I, Martello D., Bianchi N., Borgatti M., Lambrtini E.,. Piva R, Jabbars S., Choudhuri M. S., Khan M. T. and Gambari R. (2003), "In Vitro antiproliferative effect on human tumor cell lines of extracts from the bangladesi medicinal plant Aegle marmelos Correa." Phytomedicine, 10, Page No. 300-308.

[7] Karunanayake E. H., Welihinda J., Sirimanne S. R. and Sinnadorai G. (1984), "Oral hypoglycemic activity of some medicinal plants of Sri Lanka” J Ethnopharmacol, 11 Page No. 223-231. 
[8] Parmar N, Patil B, Patel B. A review on classical therapeutic uses of Bilva (Aegle marmelos Corr.). Pharma science monitor: An international journal of pharmaceutical sciences.2014;5(2):21-30.

[9] Jaswant, Akilandeswari, V. Loganathan, S. Manimaran and Ruckmani, "Wound healing activity of Aegle marmelos" Indian J. Pharm. Sci. 2001; 63(1), 41-44.

[10] Shankarananth V, Balakrishnan N, Suresh D, Sureshpandian G, Edwin E, Sheeja E. " Analgesic activity of methanol extract of Aegle marmelos leaves." Biological Trace Element Research. 2007; 78, 258 - 259.

[11] Upadhya, S., Shanbhag, K K, Suneetha, G, Naidu, B M, and Upadhya, S. (2004) "A study of hypoglycemic and antioxidant activity of Aegle marmelos in alloxan induced diabetic rats", Ind. J. Physiol. Pharmacol., 48, Page No. 476-480.

[12] Marzine, P S, and Gilbart, R. (2005), "The effect of an aqueous extract of A. marmelos fruits on serum and tissue lipids in experimental diabetes", J. Sci. Food Agriculture, 85(4), Page No.569573.

[13] Sundaram, E.N., Raddy, Uma Maheswara P and Singh K.P (2009); "Effect of Alcoholic Extracts of Indian Medicinal Plants on the Altered Enzymatic Activities of Diabetic Rats", Indian Journal of Pharmaceutical Sciences; 71(5), Page No.594-598.

[14] Kuttan, R and Sabu, M. C (2004); "Antidiabetic activity of Aegle marmelos and its relationship with its antioxidant properties", Indian J Physiol Pharmacol; 48 (1), Page No.81-88.

[15] Hema C.G and Lalithakumari K (1999); "Screening of Pharmacological actions of Aegle marmelos", Indian J. Pharmac.; 20, Page No.80-85.

[16] Singanan, V., Singanan, M and Begum H (2007); "The hepatoprotective effect of bael leaves (Aegle marmelos) in alcohol induced liver injury in albino rats"; International Journal of Science \& Technology; 2(2), Page No. 83-92.

[17] Singh R and Singh H Rao (2008) "Hepatoprotective effect of the pulp/seed of Aegle Marmelos correa ex Roxb against carbon tetrachloride induced liver damage in rats" International Journal of Green Pharmacy, Page No.232

[18] Maheshwari, V L, Joshi, P V and Patil, R H (2009); "In vitro anti diarrhoeal activity and toxicity profile of Aegle marmelos Correa ex. Roxb. dried fruit pulp", Natural Product Radiance; Vol 8 (5), Page No.498-502.

[19] Kaur, S., Kaur, P., Walia, A. and Kumar, S (2009); "Antigenotoxic Activity of Polyphenolic Rich Extracts from Aegle marmelos (L.) Correa in Human Blood Lymphocytes and E.coli PQ 37"; Rec. Nat. Prod.; 3:1, Page No. 68-75.

[20] Citarasu, T., Rajajeyasekar, R., Venkatmalingam K., Dhandapani, P. S and Peter Marian M ( 2003); "Effect of wood apple Aegle marmelos, Correa ( Diacotyledons, Sapindales, Rutaceae) Extract as an antibacterial agent on pathogens infecting prawn (Penaeus indicus) larviculture", Indian Journal of Marine Sciences; 32 (2), Page No.156-161.

*Corresponding author.

E-mail address: shailsanghi@ gmail.com 